\title{
Peculiarities of Infiltration Measurements in Water-Repellent Forest Soil
}

\author{
Tomáš Orfánus ${ }^{1}$, Anton Zvala ${ }^{1}$, Malvína Čierniková ${ }^{2, *}$, Dagmar Stojkovová $^{1}, \operatorname{Viliam}$ Nagy $^{1}$ and Pavel Dlapa $^{2}$ (D) \\ 1 Institute of Hydrology, Slovak Academy of Sciences, Dúbravská Cesta 9, 84104 Bratislava, Slovakia; \\ tomasorfanus@gmail.com (T.O.); zvala@uh.savba.sk (A.Z.); dagmar.stojkovova@gmail.com (D.S.); \\ nagy@uh.sav.sk (V.N.) \\ 2 Department of Soil Science, Faculty of Natural Sciences, Comenius University, Mlynská Dolina, Ilkovičova 6, \\ 84215 Bratislava, Slovakia; pavel.dlapa@uniba.sk \\ * Correspondence: malvina.ciernikova@uniba.sk
}

Citation: Orfánus, T.; Zvala, A.; Čierniková, M.; Stojkovová, D.; Nagy,

V.; Dlapa, P. Peculiarities of Infiltration Measurements in Water-Repellent Forest Soil. Forests 2021, 12, 472. https://doi.org/ $10.3390 /$ f12040472

Academic Editor: Manuel

Esteban Lucas-Borja

Received: 28 February 2021

Accepted: 9 April 2021

Published: 12 April 2021

Publisher's Note: MDPI stays neutral with regard to jurisdictional claims in published maps and institutional affiliations.

Copyright: (c) 2021 by the authors. Licensee MDPI, Basel, Switzerland. This article is an open access article distributed under the terms and conditions of the Creative Commons Attribution (CC BY) license (https:// creativecommons.org/licenses/by/ $4.0 /)$.
Abstract: The paper deals with measurements of water infiltration carried out on a well-developed forest floor formed by needle-leaf litter of Norway spruce. Three field methods (tension disk permeameter, single-ring infiltrometer and Guelph permeameter) were used to determine the soil hydraulic conductivity. The results were strongly influenced by the water repellency at the interface between the $\mathrm{O}$ - and A-horizons. This interface was severely water repellent during the hot and dry summer season, regardless of the generally humid mountain climate of the High Tatras foothill. The single-ring method paradoxically provided lower hydraulic conductivity $\left(3.2 \times 10^{-4} \pm 1.3 \times 10^{-4}\right)$ compared to the tension disk permeameter $\left(8.5 \times 10^{-4} \pm 3.3 \times 10^{-4}\right)$ due to the presence of the water-repellent $\mathrm{O} / \mathrm{A}$-interface. This effect was also observed with the Guelph permeameter method, which gave the lowest value $\left(5.6 \times 10^{-5} \pm 4.3 \times 10^{-5}\right)$. Abrupt retardation of infiltration on the water-repellent interface may generate shallow subsurface runoff (as was proved by the irrigation experiment) or litter splash during extreme rainfall events and promote water flow to deeper soil horizons through preferential pathways. The observed effects of the forest floor on rainfall infiltration will depend on the seasonal variability of soil water repellency. Although the forest floor is a source of hydrophobic substances that cause water repellency at the $\mathrm{O} / \mathrm{A}$-interface and can trigger runoff generation, at the same time its cohesive duff layer protects the forest soil from erosion.

Keywords: infiltration; hydraulic conductivity; soil water repellency; forest floor; Norway spruce

\section{Introduction}

The significance of forests and their quality (including forest soils) for catchment hydrology has become more approved by relevant scientific studies, especially in the context of climate change and land-use effects on water regime and increasing flood and drought risks [1]. Because they are the biggest in size and largest in distribution, forests impact on the hydrological cycle and the physical environment is the greatest among all-natural cover types on the Earth [2]. Plant and animal residues are deposited on the surface of forest and grassland soils. This material may accumulate and form a forest floor (O-horizon) overlaying mineral soil horizons. A typical sequence of horizons in the forest floor follows changes in the decomposition of organic residues. On the top, there is loose undecomposed material (Oi), followed by a horizon of fragmented and fermented residues (Oe), and the bottom part is formed by highly decomposed amorphous material (Oa). The last two horizons together form the so-called duff layer. The total amount of accumulated organic material superposing the soil profile can be substantial. Simmons [3] reported that the annual litterfall of the fir taiga ranges from 2.5 to $3.0 \mathrm{t} \cdot \mathrm{ha}^{-1}$. Jonczak [4] found that litterfall in a 120-year-old beech stand yields from 2.79 to $5.40 \mathrm{t} \cdot \mathrm{ha}^{-1}$, with the largest values appearing in its seminal years. Binkley [5] states that the mass of litterfall in 40-year-old stands of Picea strobus, Picea tremuloides, Picea glauca, Picea resinosa and Picea 
banksiana is $2.90,3.98,5.48,6.18$ and $5.75 \mathrm{t} \cdot \mathrm{ha}^{-1}$, respectively. Novak and Slodicak [6] report that the annual yield of Norway spruce (Picea abies) litterfall ranged between 1.80 and 4.80 $\mathrm{t} \cdot \mathrm{ha}^{-1}$, and the total dry biomass accumulated under the 36-year-old Norway spruce stand ranged from 9.20 to $11.30 \mathrm{t} \cdot \mathrm{ha}^{-1}$ in Oi, from 37.0 to $38.20 \mathrm{t} \cdot \mathrm{ha}^{-1}$ in Oe and from 138.30 to $146.40 \mathrm{t} \cdot \mathrm{ha}^{-1}$ in Oa. The average thickness of the forest floor under spruce stands reached $4.7-8.4 \mathrm{~cm}$ [7-9], 13-19 cm [10] or even 19-21 cm [11].

The presence of the O-horizon in forest soil profiles has a significant impact on soil processes compared to soils where this horizon is missing [12,13]. The organic horizon is specific in terms of its physical properties. It has been emphasised that organic litter material is usually characterised by high hydraulic conductivity [14-16], high water retention [15,17-19], very high porosity [20], low bulk density and loose structure [21], and even exhibits volume changes during the wetting-drying cycles [22]. The surface organic horizons of forest soils are younger compared to the deeper mineral horizons, and their properties depend to a large extent on current environmental conditions [23]. Thick forest floors are more common in cool and humid forests, where soils are acidic and decomposition is slow and incomplete [24]. The decay rate of coniferous needle litter is slower than that of hardwood leaves. In the absence of recent disturbances, forest floor masses in humid regions tend to be larger under coniferous vegetation than under deciduous vegetation. As the leaf mass increases, the interception storage capacity of the leaf litter successively increases for needle-leaf litter, while there are no apparent patterns for the broad-leaf litter [13].

There are few studies on the role of the forest floor in the rainwater infiltration process [25]. According to Guevara-Escobar et al. [26], the forest floor significantly affects the infiltration of rainwater and the formation of runoff. Li et al. [27] also conclude that the organic horizon's hydraulic properties significantly affect the flow of water into the soil profile. Variations in the litter layer thickness and porosity should be considered when analysing the effects not only on litter interception but also on water movement on the litter surface and water movement inside the litter, as well as at the interface between the forest floor and mineral soil [27].

The research of soil organic matter is a challenging discipline because of various continuous and parallel transformation processes that cause its highly variable overall biochemical composition and habitat in the whole spectrum of spatial scales. Soil organic matter is a source of hydrophobic substances that affect the soil-water contact angle [28]. The organic and organomineral horizons of forest soils are therefore often water repellent due to the presence of hydrophobic substances from litter, microbial biomass and root exudates $[29,30]$. The presence of well-developed forest O-horizons may play an important role in hydrological processes due to their water repellency and cohesion. Water repellency limits water penetration into deeper horizons, while the cohesion of the duff material may reduce the presence of preferential pathways. Hence, even in soil types with a generally high infiltration capacity and low runoff formation, forest floor horizons can cause marked changes in hydrological processes [23].

A quantitative measure of the soil's ability to transmit water is saturated hydraulic conductivity $\left(\mathrm{K}_{\mathrm{S}}\right)$. Saturated hydraulic conductivity is closely related to pore size distribution, pore shape and connectivity. The determination of $\mathrm{K}_{\mathrm{S}}$ in field conditions is extremely arduous and time consuming. In developed soil profiles, saturated hydraulic conductivity varies in the vertical direction, depending on the properties of the individual soil horizons. However, the measured Ks values also depend on the method used for their determination [31,32], and differences in Ks values produced by different methods may exceed the influence of soil properties [31]. It is therefore very important to choose a suitable method for the Ks determination, which will provide values that can be correctly interpreted in relation to real hydrological processes in soils and watersheds. However, choosing the right method and interpret the results correctly is difficult due to the lack of studies on this issue, and in this context, it is also difficult to compare the results of research where different methods have been used to determine Ks. 
There is no doubt that the forest floor is important in the redistribution of rainwater between the processes of infiltration, evaporation (including interception), water retention and runoff. Although it is tricky to interpret pedon-scale or hillslope-scale observations in the context of catchment hydrology, it is clear that there is a need to gain knowledge of the wide range of mechanisms involved in hydrological processes at the local level. The aim of this study was therefore to evaluate the impact of forest soil horizons on the infiltration process. Considering the complex nature of forest soil with various types of heterogeneity [32] and phenomena such as water repellency [25] or compaction [33], one cannot rely on a single infiltration method, which is, however, routine in many studies. A combination of three different methods (tension disk permeameter, single-ring method, Guelph permeameter) was used to identify the peculiarities that occur when rain infiltrates into layered forest soil and that affect the determination of hydraulic conductivity by different methods. The results of infiltration measurements were compared with an irrigation experiment to evaluate the likelihood of subsurface runoff generation.

\section{Materials and Methods}

\subsection{Study Site}

Field experiments were carried out on forest soil with a slope of $30^{\circ}$, at an altitude of $860 \mathrm{~m}$ a.s.1., with the coordinates $49^{\circ} 6^{\prime} 30.8^{\prime \prime} \mathrm{N}$ and $19^{\circ} 51^{\prime} 53.4^{\prime \prime} \mathrm{E}$ above the Dovalovec creek in the High Tatras (Figure 1). The average annual temperature is $4-5{ }^{\circ} \mathrm{C}\left(14-15^{\circ} \mathrm{C}\right.$ in summer), average annual relative humidity is in the range of $77.5-80.0 \%$ and the total annual precipitation is between 800 and $900 \mathrm{~mm}$ [34]. Norway spruce (Picea abies) is the main tree species of the 60-year-old forest stand, while the herb layer is dominated by the blueberry (Vaccinium myrtillus). The forest soil was classified as Dystric Cambisol [35]. The surface organic O-horizon is $3-15 \mathrm{~cm}$ thick and typically consists of two layers: the raw litter (Oi-horizon) and the duff. Where the O-horizon is at least $6 \mathrm{~cm}$ thick (most of the research area), two horizons (Oe and $\mathrm{Oa}$ ) can be visually recognised in the duff layer. Under the forest floor is a dark organomineral A-horizon, at 6-15 cm (where O-horizon is $6 \mathrm{~cm}$ thick), and a mineral B-horizon, below $23 \mathrm{~cm}$.

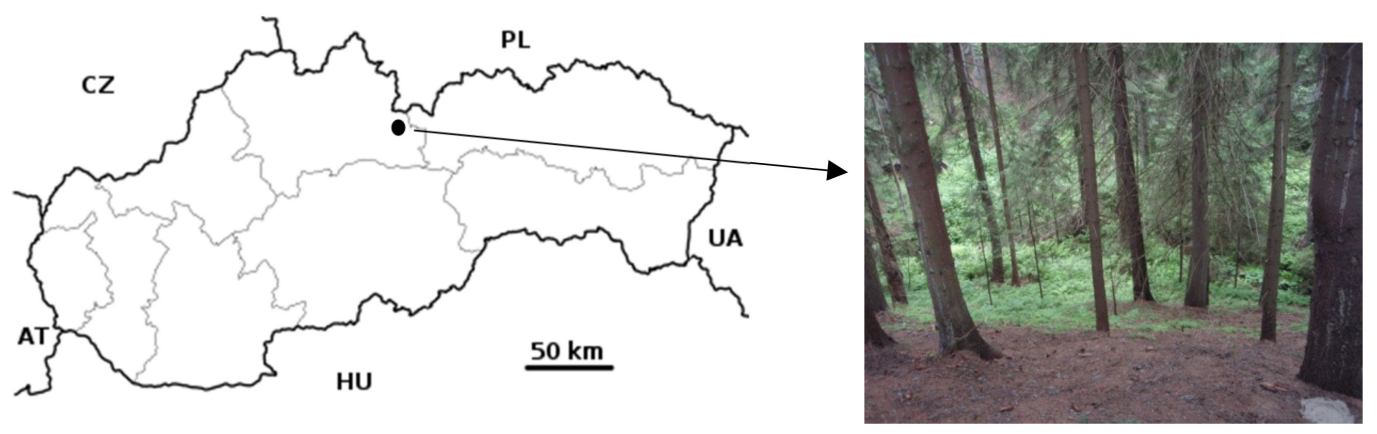

Figure 1. The study location on the High Tatras foothill. On the right is the investigated hillslope directly above the Dovalovec creek.

\subsection{Infiltration Tests and Hydraulic Conductivity Determination}

Infiltration experiments took place during the extremely hot and dry summer season of 2015. The dry season started in April and lasted until September. Later in October and November, precipitation was above normal. Infiltration measurements were randomly distributed over an area of $15 \times 45 \mathrm{~m}^{2}$ on naturally flat relief segments with well-developed O-horizons. Subplots for individual infiltration tests were chosen so as to avoid interference with each other.

The tension disk permeameter measurements were performed on the O-horizon surface. This method is applicable to soils containing a significant portion of macropores and/or preferential flow paths, which are excluded from the hydraulic conductivity calculation. The water infiltration running at the negative water potential established on the soil 
surface provides the hydraulic conductivity of the soil matrix. The determined hydraulic conductivity should therefore be regarded as the near-saturated hydraulic conductivity. The tensions applied here were $\mathrm{h}_{1}=-4 \mathrm{~cm}$ and $\mathrm{h}_{2}=-6 \mathrm{~cm}$, and the disk radius was 10.0 $\mathrm{cm}$. The $\mathrm{K}_{\mathrm{S}-\mathrm{DP}}$ calculation was performed according to the user manual [36].

The single-ring method was used as a standard method to evaluate the vertical component of hydraulic conductivity. In our study, we used a metal ring with a diameter of $30 \mathrm{~cm}$ and a height of $25 \mathrm{~cm}$, which was inserted into the forest floor down to the required depth (here down to the interface between the forest floor and the A-horizon) but not less than $10 \mathrm{~cm}$ deep. Inside the ring, there was a perforated circular plate, which prevented the forest floor material from being washed out during the water application to the forest floor surface. The water table (ponding) was set to $5 \mathrm{~cm}$. The time intervals of the water table dropping by $2 \mathrm{~cm}$ (from 5 to $3 \mathrm{~cm}$ ) were repeatedly recorded until a steady flow was reached. From the measured volumes of infiltrated water versus time $(t)$, we determined a steady flow rate $(\mathrm{Q})$. The saturated hydraulic conductivity $\mathrm{K}_{\mathrm{S}-\mathrm{SR}}$ was then calculated according to Reynolds and Elrick [37].

The Guelph permeameter method, which was also tested, is an experimental field method that uses the Mariotte principle to adjust the ponding level in a drilled hole. It is a well-documented device, and we used the standard measurement procedure as described in the operating instructions [38]. Measured $\mathrm{K}_{\mathrm{S}-\mathrm{GP}}$ values express the integral vertical and horizontal conductivity of the soil, including macropores and preferential pathways. The measurements were performed in $12 \mathrm{~cm}$ deep holes (through the forest floor to the top of the A-horizon) on six subplots in the research area. The ponding was set to $5 \mathrm{~cm}$ and $10 \mathrm{~cm}$, respectively. The $\mathrm{K}_{\mathrm{S}-\mathrm{GP}}$ was calculated according to the operating manual [38].

In addition, the soil water repellency of the $\mathrm{O} / \mathrm{A}$-interface was evaluated by a water drop penetration time (WDPT) test [39] and using a Mini Disk Infiltrometer [40]. The WDPT measurement was performed on 29 samples of the O/A-interface during the summer and autumn seasons. The WDPT was determined in the field by placing three drops of distilled water from a medicinal dropper (drop volume: $58 \pm 5 \mu \mathrm{L}$ ) on disturbed soil samples taken from the interface between the O- and A-horizon and measuring the time of their imbibition. The WDPT values were calculated as an average of three imbibition times and classified as: wettable soil ( $<5$ s); slightly (5-60 s), strongly (60-600 s), severely (600$3600 \mathrm{~s}$ ) and extremely (>3600 s) water-repellent soil [41]. The near-saturated hydraulic conductivity of the interface was measured for water $\mathrm{K}_{\mathrm{MD} \text {-w }}$ and ethanol $\mathrm{K}_{\mathrm{MD} \text {-e }}$ by the Mini Disk Infiltrometer [40] with a disk radius of $2.25 \mathrm{~cm}$ and with a small negative pressure head $\left(\mathrm{h}_{0}=-2 \mathrm{~cm}\right)$ applied to the $\mathrm{O} / \mathrm{A}$-interface.

\subsection{Irrigation Experiment}

To perform the irrigation experiment, an $80 \mathrm{~cm}$ deep soil profile was opened (Table 1) in the lower part of the research plot not affected by the infiltration tests. A set of two troughs was installed, as shown in Figure 2, to collect the water discharged from the irrigated area. The first trough was inserted into the O/A-interface, while the second trough was inserted into the upper part of the B-horizon. The B-horizon was less permeable than the A-horizon due to the higher clay and rock content (Table 1). The soil water content was determined before and after each irrigation event using a Theta Probe Soil Moisture Sensor ML2× (Delta T Devices Cambridge, England) in ten repetitions evenly distributed on the experimental plot $\left(2 \mathrm{~m}^{2}\right)$. The irrigated experimental plot was $1 \mathrm{~m}$ wide and $2 \mathrm{~m}$ long, situated uphill above the soil profile with installed troughs (Figure 2). The seepage water was caught in troughs and from there via pipes transferred to automatic flip rain gauges, where it was recorded. To avoid excessive water leakage into the dryer soil surrounding the experimental plot, the total irrigated area was $6 \mathrm{~m}^{2}$ ( $3 \mathrm{~m}$ wide and $2 \mathrm{~m}$ long). 
Table 1. Morphology of the opened forest soil profile.

\begin{tabular}{|c|c|c|}
\hline Soil Depth (cm) & Horizon & Description \\
\hline $0-2$ & Oi & $\begin{array}{l}\text { Undecomposed organic material, dominated by spruce needles and twigs, } \\
\text { loose consistency }\end{array}$ \\
\hline $2-5$ & Oe & $\begin{array}{l}\text { Partially decomposed needles and twigs material, aggregated, tenacious } \\
\text { consistency }\end{array}$ \\
\hline $5-6$ & $\mathrm{Oa}$ & $\begin{array}{c}\text { Dark brown transformed organic material, fine humified components } \\
\text { predominate over plant residues }\end{array}$ \\
\hline $6-15$ & Ah & $\begin{array}{c}\text { Dark brown, loamy texture, weak medium crumby to subangular blocky } \\
\text { structure, } 10 \text { vol.\% coarse fragments }\end{array}$ \\
\hline $15-23$ & $\mathrm{AhBw}$ & Brown, loamy texture, weak medium subangular blocky structure \\
\hline $23-55$ & Bw & $\begin{array}{l}\text { Reddish-brown, loamy texture, but more clayey than Ah horizon, moderate } \\
\text { medium subangular blocky structure, } 35 \text { vol. } \% \text { coarse fragments }\end{array}$ \\
\hline $55-80$ & $\mathrm{BwC}$ & $\begin{array}{l}\text { Pale brown, loamy texture, moderate medium subangular blocky structure, } \\
\qquad 50 \text { vol. } \% \text { coarse fragments }\end{array}$ \\
\hline
\end{tabular}
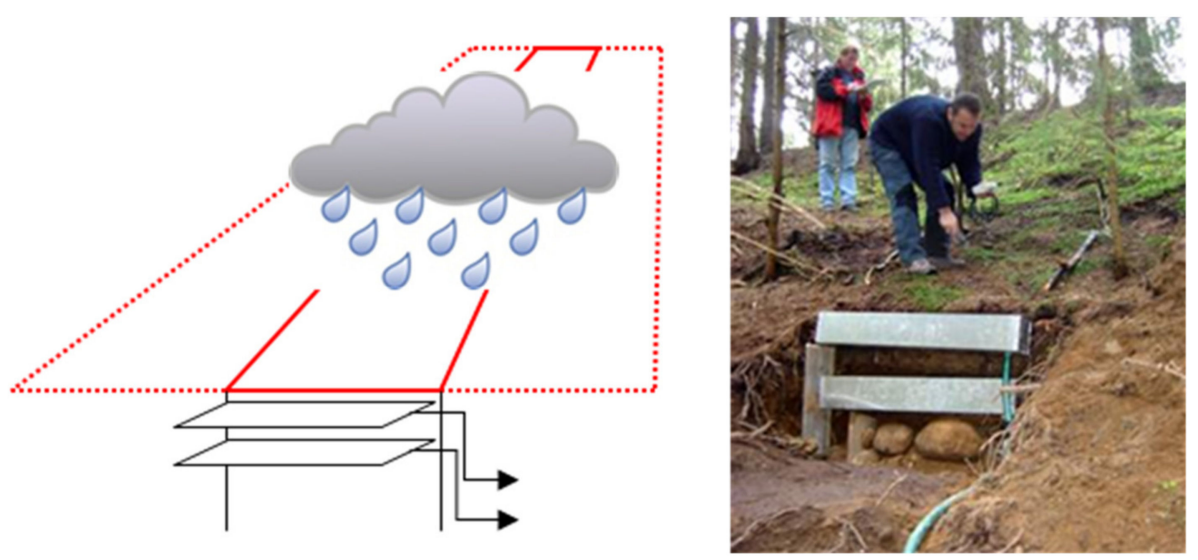

Figure 2. Scheme of the field irrigation experiment with outflow recording. The dotted lines demarcate the total irrigated area $\left(6 \mathrm{~m}^{2}\right)$, while the solid lines delimit the experimental area $\left(2 \mathrm{~m}^{2}\right)$ where the water balance was determined.

The irrigation was performed using an adapted garden sprinkler with adjustable pressure and droplet size. Two precipitation events were simulated in the course of the experiment. The first simulation represented a relatively high rainfall amount $(33 \mathrm{~mm})$ applied to rather dry soil (average forest floor water content was $14.5 \mathrm{vol} . \%$ ) over three hours. Such high precipitation has a periodicity of 2-5 years for meteorological stations in this region. The second simulation was performed $15 \mathrm{~h}$ after the first and represented precipitation of $8.3 \mathrm{~mm}$ applied to relatively wet soil (average topsoil moisture was $29 \mathrm{vol} . \%$ ) over $30 \mathrm{~min}$. Such (or higher) precipitation events occur several times a year here.

\section{Results}

\subsection{Hydraulic Conductivity of Surface Organic Horizon}

The hydraulic conductivities determined by three different methods are listed in Table 2. It is obvious that the values can differ up to 100 -fold between the different methods. The influence of the applied method here is much larger than the spatial variability of measured values, as seen in Figure 3. This must be taken into account in explaining the role of a spruce forest floor in hydrological processes. 
Table 2. Hydraulic conductivity of the forest floor determined by three different methods with average and standard deviation (SD) values.

\begin{tabular}{cccc}
\hline Location & DP & SR & GP \\
\hline & $\begin{array}{c}\mathrm{K}_{\mathrm{S}-\mathrm{DP}} \\
\left(\mathrm{m} \cdot \mathrm{s}^{-1}\right)\end{array}$ & $\begin{array}{c}\mathrm{K}_{\mathrm{S}-\mathrm{SR}} \\
\left(\mathrm{m} \cdot \mathrm{s}^{-1}\right)\end{array}$ & $\begin{array}{c}\mathrm{K}_{\mathrm{S}-\mathrm{GP}} \\
\left(\mathrm{m} \cdot \mathrm{s}^{-1}\right)\end{array}$ \\
\hline 1. & $7.87 \times 10^{-4}$ & $2.85 \times 10^{-4}$ & $7.52 \times 10^{-5}$ \\
2. & $1.15 \times 10^{-3}$ & $4.60 \times 10^{-4}$ & $1.68 \times 10^{-5}$ \\
3. & $1.33 \times 10^{-3}$ & $1.62 \times 10^{-4}$ & $1.59 \times 10^{-5}$ \\
4. & $6.14 \times 10^{-4}$ & $3.14 \times 10^{-4}$ & $8.53 \times 10^{-5}$ \\
5. & $8.07 \times 10^{-4}$ & $2.17 \times 10^{-4}$ & $11.8 \times 10^{-5}$ \\
6. & $4.48 \times 10^{-4}$ & $4.91 \times 10^{-4}$ & $2.50 \times 10^{-5}$ \\
Average & $8.56 \times 10^{-4}$ & $3.22 \times 10^{-4}$ & $5.60 \times 10^{-5}$ \\
SD & $3.30 \times 10^{-4}$ & $1.31 \times 10^{-4}$ & $4.28 \times 10^{-5}$ \\
\hline
\end{tabular}

Methods: DP—disk permeameter, SR—single ring, GP—Guelph permeameter.

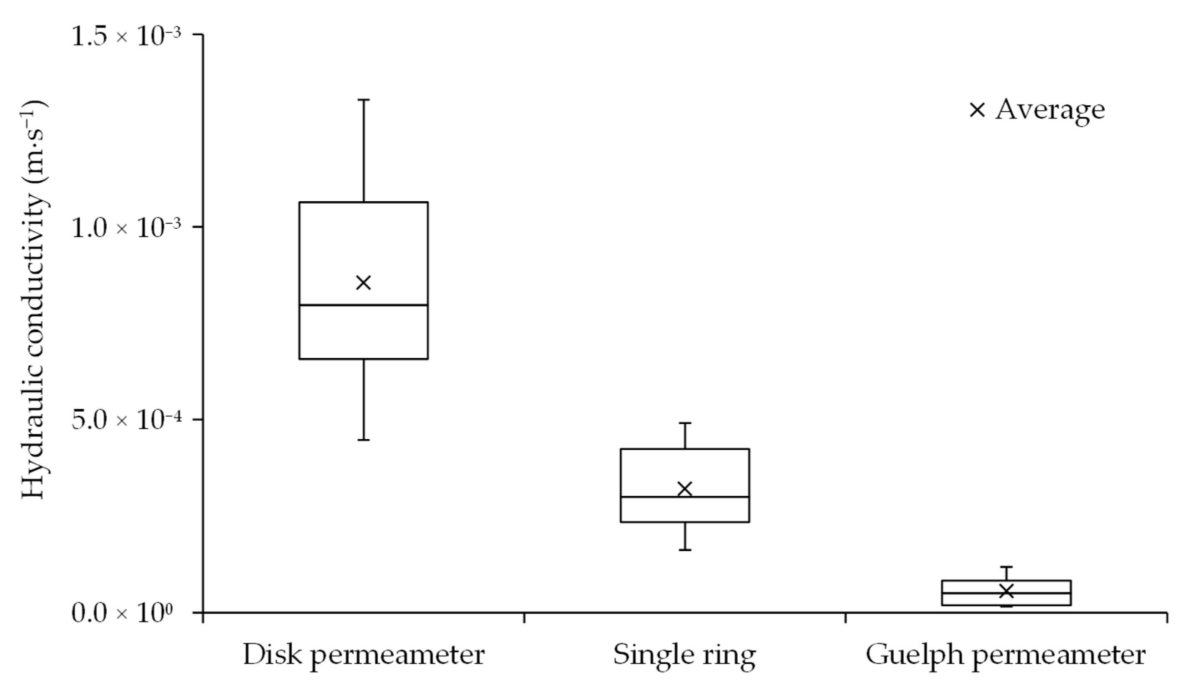

Figure 3. Differences in hydraulic conductivities determined by three different methods.

The tension disk permeameter method prevents ponding because it maintains a small negative pressure (tension) on the forest floor surface. In addition, its installation on the surface of the forest floor eliminates the influence of the water-repellent interface between the duff layer and A-horizon. For these reasons, we consider the tension disk permeameter method to be suitable for $\mathrm{K}_{\mathrm{S}}$ estimation in the research of hydrological processes under normal meteorological situations when there is no ponding on the soil surface during rain. The average $\mathrm{K}_{\mathrm{S} \text {-DP }}$ value was $8.56 \times 10^{-4} \mathrm{~m} \cdot \mathrm{s}^{-1}$.

In the single-ring method, water flows through the volume of soil bounded by the walls of the stainless steel cylinder. The cylinder is inserted into the soil, and the measured values characterise the properties of the soil layers inside the cylinder. The $\mathrm{K}_{\mathrm{S}}$ values obtained by this method were significantly lower compared to the tension disk permeameter results (Table 2, Figure 3), and this is uncommon. This is due to the presence of a subsurface water-repellent layer at the interface between the $\mathrm{O}$ - and A-horizons (Figure 4). The cylinder was inserted through the O-horizon to the upper part of the A-horizon and the water-repellent $\mathrm{O} / \mathrm{A}$-interface was therefore located inside the cylinder. This water-repellent interface affected the results of the individual methods in different ways. In the case of the single-ring method, the presence of a water-repellent layer inside the cylinder caused a significant reduction in the measured $\mathrm{K}_{\mathrm{S}-\mathrm{SR}}$ value $\left(3.22 \times 10^{-4} \mathrm{~m} \cdot \mathrm{s}^{-1}\right)$, while the measurement performed by a disk permeameter on the soil surface was not affected. This conclusion is also supported by the results obtained by the Guelph method. 


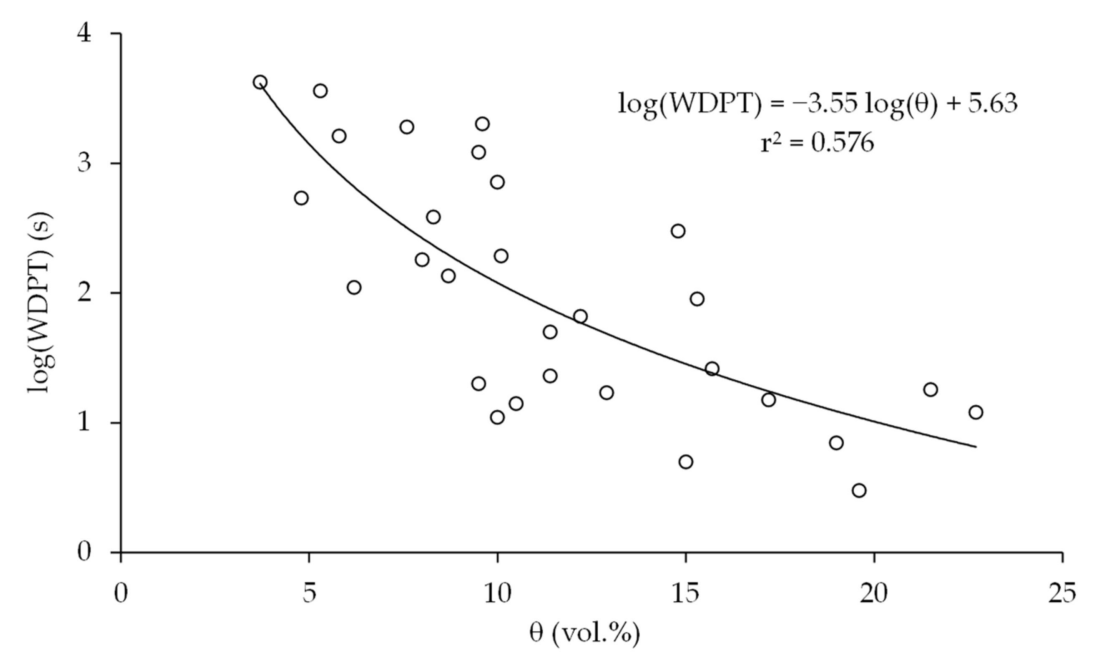

Figure 4. Average values of the water drop penetration time (WDPT) detected at the O/A-interface as a function of soil water content.

The lowest hydraulic conductivities were determined by the Guelph permeameter method. The reason for these surprising results is that the measurement includes not only the O-horizon but also the water-repellent $\mathrm{O} / \mathrm{A}$-interface. This water repellency caused substantial retardation of the vertical component of hydraulic conductivity. The average $\mathrm{K}_{\mathrm{S}-\mathrm{GP}}$ was $5.60 \times 10^{-5} \mathrm{~m} \cdot \mathrm{s}^{-1}$, which was an order of magnitude lower than the $\mathrm{K}_{\mathrm{S}}$ determined by the other two methods.

The water repellency at the interface between the O- and A-horizons, which significantly affected $\mathrm{K}_{\mathrm{S}}$ values determined by the single-ring and the Guelph permeameter methods, was detected in two ways: by the WDPT test and by comparing the hydraulic conductivities for water and ethanol measured using a Mini Disk Infiltrometer. The water permeability was extremely low compared to ethanol and with regard to soil porosity at the $\mathrm{O} / \mathrm{A}$-interface. The $\mathrm{K}_{\mathrm{MD}-\mathrm{w}}$ values of $2.73 \times 10^{-7}, 5.41 \times 10^{-7}$ and $1.64 \times 10^{-6} \mathrm{~m} \cdot \mathrm{s}^{-1}$ were one to two orders of magnitude lower than the $\mathrm{K}_{\mathrm{MD} \text {-e }}$ values of $2.20 \times 10^{-5}, 1.33 \times 10^{-5}$ and $4.96 \times 10^{-5} \mathrm{~m} \cdot \mathrm{s}^{-1}$. The WDPT values revealed that the severity of water repellency at the $\mathrm{O} / \mathrm{A}$-interface is strongly dependent on soil moisture (Figure 4). In the summer season, the samples from the $\mathrm{O} / \mathrm{A}$-interface were severely water repellent with an average WDPT of $927 \mathrm{~s}$, while in the autumn, the samples were strongly water repellent with an average WDPT of $71 \mathrm{~s}$. Only one sample was wettable with a WDPT of $3 \mathrm{~s}$ in autumn. It can be assumed that water repellency significantly contributes to the reduction of hydraulic conductivity in this part of the soil profile.

\subsection{Irrigation Experiment}

The water balance of the irrigated plot $\left(2 \mathrm{~m}^{2}\right)$ is given in Table 3 . The average soil water content in the forest floor layer has increased by $22 \mathrm{vol} . \%$ after the first irrigation dosage (33 $\mathrm{mm}$ in $3 \mathrm{~h}$ ). It represents about $13 \mathrm{~mm}$ of water column in a forest floor $60 \mathrm{~mm}$ deep. This means that $39 \%$ of the irrigated water, which was $33 \mathrm{~mm}$, was either intercepted or otherwise retained by the forest floor horizon. Another $20 \mathrm{~mm}$ of applied irrigation percolated deeper into the soil profile through the organomineral A-horizon or drained laterally. 
Table 3. Water balance in the irrigation experiment calculated for the forest floor horizon with a depth of $6 \mathrm{~cm}$. Soil water contents are averages from 10 evenly distributed measurements.

\begin{tabular}{cccccc}
\hline $\begin{array}{c}\text { Irrigation } \\
\text { Event }\end{array}$ & $\begin{array}{c}\text { Antecedent } \\
\text { SWC (Vol.\%) }\end{array}$ & $\begin{array}{c}\text { Irrigation } \\
\text { Amount } \\
\mathbf{( m m )}\end{array}$ & $\begin{array}{c}\text { Post- } \\
\text { Irrigation } \\
\text { SWC (Vol.\%) }\end{array}$ & $\begin{array}{c}\text { Subsurface } \\
\text { Runoff (mm) }\end{array}$ & $\begin{array}{c}\text { Deeper } \\
\text { Percolation } \\
\text { (mm) }\end{array}$ \\
\hline $\begin{array}{c}\text { 1st irrigation } \\
\text { 2nd } \\
\text { irrigation }\end{array}$ & 14.5 & 33 & 36.5 & 0.32 & 20.0 \\
SWC: soil water content. & 29.0 & 8.3 & 44.0 & 0.13 & 0.0 \\
\hline
\end{tabular}

The application of $33 \mathrm{~mm}$ precipitation for three hours, representing the 2-5 years periodicity of rains in the High Tatras, caused zero surface runoff but a detectable subsurface runoff. The $\mathrm{K}_{\mathrm{S}}$ (Table 2 and Figure 3) of the forest floor horizon was by two orders larger than the irrigation intensity, while the unsaturated hydraulic conductivity $\left(\mathrm{K}_{\mathrm{MD}-\mathrm{w}}\right)$ of the soil matrix in the water-repellent $\mathrm{O} / \mathrm{A}$-interface (average value determined with a Mini Disk Infiltrometer: $8.2 \times 10^{-7} \mathrm{~m} \cdot \mathrm{s}^{-1}=2.95 \mathrm{~mm}$ per hour) was about four times lower than the applied irrigation intensity. This means that the water irrigated on the forest floor surface reaches the water-repellent $\mathrm{O} / \mathrm{A}$-interface and then either moves laterally along a steep slope or infiltrates deeper through preferential pathways. The redistribution of rainwater between subsurface runoff and deep infiltration can be crucial for triggering floods and erosion.

The subsurface water seepage was observed evenly over the top (35-cm thick) forehead of the uncovered soil profile with installed troughs. The total subsurface runoff from the $2 \mathrm{~m}^{2}$ experimental plot detected by ombrographs was only $0.64 \mathrm{~L}$, which represents only $1 \%$ of the total irrigation water applied. Shallow subsurface runoff was detected $16 \mathrm{~min}$ after the beginning of the irrigation, while the deeper subsurface runoff (from the soil layer below the A-horizon) was delayed by $2 \mathrm{~h}$. Continual subsurface water seepage was observable for $5 \mathrm{~h}$, and a substantial part of it continued at a uniform intensity. These observations indicate a real possibility of shallow runoff generation even under unsaturated conditions when the water-repellent $\mathrm{O} / \mathrm{A}$-interface is present in the soil profile. Such runoff need not be observable by the eye because the water first passes through the highly porous and conductive forest floor horizon and therefore remains masked.

The application of $8.3 \mathrm{~mm}$ precipitation in 30 min during the second irrigation caused a subsurface runoff of only $0.13 \mathrm{~mm}$, which is approximately $1.6 \%$ of the amount of irrigation water applied. The soil therefore retained $8.2 \mathrm{~mm}$ from the precipitation applied, which corresponds to an increase in soil moisture of the $60 \mathrm{~mm}$ thick O-horizon by $14 \mathrm{vol} . \%$. This value roughly corresponds to the average water content in the forest floor increased by $15 \mathrm{vol} . \%$. In this case, the subsurface runoff was detected only from the upper layer of the forest floor and became observable after $14 \mathrm{~min}$ of irrigation. Its substantial part continued at a steady intensity and took approximately $1 \mathrm{~h}$ to complete.

\section{Discussion}

Our research on the water infiltration into the forest floor layer has raised several issues that should be discussed. Despite the steep slope of the research site, the forest floor was well developed there. It typically consisted of two or three distinct layers, the raw litter (Oi-horizon) and the duff layer, the latter mostly being differentiated into the horizons Oe and Oa. Its thickness ranged typically from 3 to $15 \mathrm{~cm}$ or locally even more at the study location, which is comparable to the values reported in the literature for Norway spruce forests [7-11]. This means that the organic matter accumulation prevails over its mineralisation and/or denudation processes in the local humid climate, which also causes the leaching of hydrophobic substances from the needle detritus.

Hydrophobic substances in the soil cause the soil water repellency during most of the year (even in late autumn), which is not in line with most literature [23,29,30], as it is generally believed that soil water repellency is mainly related to warmer and drier climates. However, the impact of climate on soil water repellency in dry climates may be limited 
due to the low organic matter content of soils compared to humid climates [33]. The study site was affected by soil water repellency, especially at the $\mathrm{O} / \mathrm{A}$-interface. This was also the main reason for the evaluation of a set of standard field methods used in this research.

The hydraulic conductivities determined here by the tension disk permeameter method (average value equal to $8.56 \times 10^{-4} \mathrm{~m} \cdot \mathrm{s}^{-1}$ ) are close to values of $7.92 \times 10^{-4}$ and $1.24 \times 10^{-3} \mathrm{~m} \cdot \mathrm{s}^{-1}$, reported for comparable soil properties by Hlaváčiková et al. [42]. This type of measurement corresponds to the infiltration of low- to medium-intensity rainfall. Under such conditions, only a local surface runoff can temporarily be formed on the forest floor surface. However, it quickly infiltrates through the macropores into the body of the forest floor horizon.

The water-repellent O/A-interface dramatically affects Guelph permeameter measurements because this interface almost completely eliminates the vertical component of hydraulic conductivity. Here, the values measured by this method were the lowest of all the methods used. It is interesting, however, that the macropores were missing or inactive on the bottom of the borehole. It is most probably due to their clogging during the borehole preparation. The conditions simulated by the Guelph method in the soil profile with the water-repellent $\mathrm{O} / \mathrm{A}$-interface are similar but not identical to real conditions during heavy rains, which can trigger a shallow subsurface lateral runoff. To support this theory, we performed an irrigation experiment to measure subsurface runoff generation.

Single-ring measurements provided hydraulic conductivities between the values obtained with a tension permeameter and the Guelph method. Although the single-ring results were also affected by the presence of a water-repellent $\mathrm{O} / \mathrm{A}$-interface at the bottom of the steel ring, higher values compared to the Guelph method indicate the presence of active preferential pathways across the water-repellent layer.

Considering our results from two irrigation experiments together with data on the hydraulic conductivity of the forest floor given by infiltration tests, it can be stated that in soils with a water-repellent $\mathrm{O} / \mathrm{A}$-interface, a lateral subsurface runoff may form even during normal rains, which affects relatively dry soils (unsaturated) on the catchment hillslopes. This supports the observations of Neris et al. [25]. They reported that rainfall above $20 \mathrm{~mm}$ per hour already triggers runoff on sloping areas covered with coniferous forests due to the presence of a water-repellent forest floor. Thus, a shallow lateral runoff can occur not only in the saturated soil above the less permeable B-horizon enriched with clay and coarse rock fragments, as described by several authors [43-45], but similar runoff can develop under certain conditions (water-repellent $\mathrm{O} / \mathrm{A}$-interface) also very close to the soil surface, and a substantial part of the runoff can run just through the forest floor, as Whipkey has already stated [46] and was pointed out in our study here.

However, the water balance of the irrigation experiment suggests that up to $20 \mathrm{~mm}$ of the simulated precipitation $(33 \mathrm{~mm})$ penetrated deeper into the soil profile. These results indicate that although water repellency at the interface inhibits matrix infiltration, water can still penetrate deeper mineral horizons through preferential pathways. The results suggest that the main properties influencing the infiltration appear to be the cohesion and water repellency of the O/A-interface, as also emphasised by Neris et al. [25] for the duff layer. Zhang et al. [47] pointed out that an increase in water repellency and a consequent decrease in infiltration rate on a millimetre (matrix) scale increases rainwater flow to deeper soil horizons, where it forms a water supply for vegetation.

The results of this study showed that the effects observed during laborious irrigation experiments can be revealed by a suitable combination of methods for determining hydraulic conductivity. It is not easy to explain the differences in the values of hydraulic conductivities obtained by different methods. Jačka et al. [48] observed differences in values determined using a Guelph permeameter, a single-ring infiltrometer and a laboratory permeameter. They explained the differences observed in podzolic soil by the influence of entrapped air or different flow geometries in different methods. However, our results revealed that the individual methods are differently sensitive to the presence of the subsurface water-repellent layer. While the tension disk permeameter determines the 
penetration of water through the surface into the very porous O-horizon, the single-ring infiltrometer or the Guelph penetrometer respond very sensitively to the presence of a water-repellent layer deeper below the surface.

The influence of the litter layer on processes associated with rain infiltration into soil depends on several factors. During short and heavy rains, the litter layer will retain less water [49-51] than during longer, less intense rainfalls [52]. Large differences in hydrological properties were also observed for litter derived from different tree species [53]. The slope inclination also has a fundamental effect on the formation of the subsurface runoff, with the greater inclination supporting the higher runoff [53]. The overall quantitative effect of the litter layer depends on its thickness, with the thicker layer retaining more water as long as other conditions are comparable [54].

The relationship between soil moisture and water repellency (Figure 4) suggests that the distribution of rainwater water among the individual components (e.g., subsurface runoff, deeper percolation, interception) is seasonally dependent on the severity of water repellency at the O/A-interface. Seasonal changes in soil water repellency have been reported by many authors [55-59].

The forest floor is a source of hydrophobic substances that cause water repellency at the interface with the mineral A-horizon and can trigger a lateral runoff, but at the same time its cohesive duff layer protects the forest soil from erosion. Neris et al. [25] emphasised that the duff layer, regardless of the reduction of the infiltration rate due to water repellency, protects the forest soil from erosion, which is also confirmed by our observations in the research area and its surroundings.

\section{Conclusions}

The results of the field experiments revealed that in the study of water infiltration in soils with a water-repellent layer below the soil surface, individual methods provide different data on the infiltration process. The disk permeameter method used for measurements on the forest floor surface provided the highest value of hydraulic conductivity. Significantly lower values were detected using a single-ring infiltrometer and a Guelph permeameter, as these measurements were affected by a severely water-repellent interface between the $\mathrm{O}$ - and A-horizons.

Based on the measurements of hydraulic conductivity by three different methods, the results of the irrigation experiment and a comparison of the relevant literature, we conclude that the forest floor layer contains a large amount of macropores creating the preferential flow domain that represents a large part of the forest floor volume.

The upper part of the forest floor with high hydraulic conductivity prevents the formation of surface runoff. The presence of the water-repellent O/A-interface, however, causes the formation of a shallow subsurface runoff even during normal rainfall. Water repellency also promotes water flow to deeper horizons through preferential pathways, which is an important process, as shown in the irrigation experiment. The resulting rainwater distribution among the interception, the shallow subsurface runoff and the deeper percolation will depend on the rain intensity and will be seasonally dependent on the temporal variability of soil water repellency.

Although the forest floor is a source of hydrophobic substances that cause severe water repellency at the interface with the organomineral A-horizon, at the same time, due to its cohesion, the duff layer protects the forest soil from erosion.

Author Contributions: Conceptualization, T.O., M.Č. and P.D.; methodology, T.O. and P.D.; formal analysis, T.O., A.Z., D.S. and M.Č.; investigation, T.O., A.Z., D.S., M.Č., V.N. and P.D.; resources, T.O. and P.D.; writing — original draft preparation, T.O., A.Z., D.S., M.Č., V.N. and P.D.; writing—review and editing, T.O., M.C.. and P.D.; supervision, T.O. and P.D.; project administration, T.O., M.Č. and P.D. All authors have read and agreed to the published version of the manuscript.

Funding: This research was funded by the Slovak Scientific Grant Agency VEGA projects 1/0712/20 and 2/0096/19. 
Institutional Review Board Statement: Not applicable.

Informed Consent Statement: Not applicable.

Data Availability Statement: Data is contained within the article.

Conflicts of Interest: The authors declare no conflict of interest.

\section{References}

1. Hlásny, T.; Sitková, Z.; Barka, I. Regional assessment of forest effects on watershed hydrology: Slovakia as a case study. J. For. Sci. 2013, 59, 405-415. [CrossRef]

2. Chang, C.; Hamburg, S.; Hwong, J.; Lin, N.; Hsueh, M.; Chen, M.; Lin, T.-C. Impacts of tropical cyclones on hydrochemistry of a subtropical forest. Hydrol. Earth Syst. Sci. 2013, 17, 3815-3826. [CrossRef]

3. Simmons, I.G. The Ecology of Natural Resources; Edward Arnold: London, UK, 1974; p. 424.

4. Jonczak, J. Dynamics, structure and properties of plant litterfall in a 120-year old beech stand in Middle Pomerania between 2007-2010. Soil. Sci. Ann. 2013, 64, 8-13. [CrossRef]

5. Binkley, D. The influence of tree species on forest soils: Processes and patterns. In Proceedings of the Trees and Soil Workshop; Agronomy Society of New Zealand special publication no. 10., Lincoln, NZ, USA, 28 February-2 March 1994; Lincoln University Press: Canterbury, NZ, USA, 1995; pp. 1-33.

6. Novak, J.; Slodicak, M. Structure and accumulation of litterfall under Norway spruce stands in connection with thinning. J. For Sci. 2004, 50, 101-108. [CrossRef]

7. Hansson, K.; Helmisaari, H.; Sah, S.; Lange, H. Fine root production and turnover of tree and understorey vegetation in Scots pine, silver birch and Norway spruce stands in SW Sweden. For. Ecol. Manag. 2013, 309, 58-65. [CrossRef]

8. Labaz, B.; Galka, B.; Bogacz, A.; Waroszewski, J.; Kabala, C. Factors influencing humus forms and forest liter properties in the mid-mountains under temperate climate of southwestern Poland. Geoderma 2014, 230-231, 265-273. [CrossRef]

9. Kristensen, T.; Naesset, E.; Ohlson, M.; Bolstad, P.V.; Kolka, R. Mapping above- and below-ground carbon pools in boreal Forests: The case for airborne Lidar. PLoS ONE 2015, 10, e0138450. [CrossRef] [PubMed]

10. Chuman, T.; Oulehle, F.; Zajícová, K.; Hruška, J. The legacy of acidic deposition controls soil organic carbon pools in temperate forests across the Czech Republic. Eur. J. Soil Sci. 2020. [CrossRef]

11. Yu, Z.; Apps, M.J.; Bhatti, J.S. Implications of floristic and environmental variation for carbon cycle dynamics in boreal forest ecosystems of central Canada. J. Veg. Sci. 2002, 13, 327-340. [CrossRef]

12. Keith, D.M.; Johnson, E.A.; Valeo, C. A hillslope forest floor (duff) water budget and the transition to local control. Hydrol. Process. 2010, 24, 2738-2751. [CrossRef]

13. Zhao, Z.; Wei, X.; Wang, X.; Ma, T.; Huang, L.; Gao, H.; Jun, F.; Li, X.; Jia, X. Concentration and mineralization of organic carbon in forest soils along a climatic gradient. For. Ecol. Manag. 2019, 432, 246-255. [CrossRef]

14. Pavao, L.L.; Sanchez, L.; Pinto, O.O.; Spolador, J. The influence of litter on soil hydro-physical characteristics in an area of Acuri palm in the Brazilian Pantanal. Ecohydrol. Hydrobiol. 2019, 19, 642-650. [CrossRef]

15. Feng, G.; Adeli, A.; Read, J.; McCarty, J.; Jenkins, J. Consequences of pelletized poultry litter applications on soil physical and hydraulic properties in reduced tillage, continuous cotton system. Soil Till. Res. 2019, 194, 104309. [CrossRef]

16. Gonzales-Sosa, E.; Braud, I.; Dehotin, J.; Lassabatère, L.; Angulo-Jaramillo, R.; Lagouy, M.; Branger, F.; Jacqueminet, C.; Kermadi, S.; Michel, K. Impact of land use on the hydraulic properties of the topsoil in a small French catchment. Hydrol. Process. 2010, 24, 2382-2399. [CrossRef]

17. Keith, D.M.; Johnson, E.A.; Valeo, C. Moisture cycles of the forest floor organic layer (F and H layers) during drying. Water Resour. Res. 2010, 46, W07529. [CrossRef]

18. Lauren, A.; Mannerkoski, H. Hydraulic properties of mor layers in Finland. Scand. J. For. Res. 2001, 16, 429-441. [CrossRef]

19. Lauren, A.; Mannerkoski, H.; Orjasniemi, T. Thermal and aeration properties of mor layers in Finland. Scand. J. For. Res. 2000, 15, 433-444. [CrossRef]

20. Kosugi, K. New Diagrams to Evaluate Soil Pore Radius Distribution and Saturated Hydraulic Conductivity of Forest Soil. J. For. Res. 1997, 2, 95-101. [CrossRef]

21. Bútorová, J.; Bedrna, Z. Contribution to the determination of soil organic horizons texture. Phytopedon 2012, 7, 51-58.

22. Orfánus, T.; Zvala, A.; Nagy, V. Water infiltration into forest soil-What do measurements signalize? In Current Problems of the Soil Aeration Zone under Conditions of Climate Change; Veda: Bratislava, Slovakia, 2018; pp. 54-79.

23. Kodešová, R.; Pavlů, L.; Kodeš, V.; Žigová, A.; Nikodem, A. Impact of spruce forest and grass vegetation cover on soil micromorphology and hydraulic properties of organic matter horizon. Biologia 2007, 62, 565-568. [CrossRef]

24. Currie, W.S.; Yanai, R.D.; Piatek, K.B.; Prescott, C.E.; Goodale, C.L. Processes affecting carbon storage in the forest floor and in downed woody debris. In The Potential of US Forest Soil to Sequester Carbon and Mitigate the Greenhouse Effect; Kimble, J.M., Lal, R., Birdsey, R., Heath, L.S., Eds.; CRC Press: Boca Raton, FL, USA, 2002; pp. 135-157.

25. Neris, J.; Tejedor, M.; Rodríguez, M.; Fuentes, J.; Jiménez, C. Effect of forest floor characteristics on water repellency, infiltration, runoff and soil loss in Andisols of Tenerife (Canary Islands, Spain). Catena 2013, 108, 50-57. [CrossRef]

26. Guevara-Escobar, A.; Gonzalez-Sosa, E.; Ramos-Salinas, M.; Hernandez-Delgado, G.D. Experimental analysis of drainage and water storage of litter layers. Hydrol. Earth Syst. Sci. 2007, 11, 1703-1716. [CrossRef] 
27. Li, X.; Niu, J.; Xie, B. The effect of leaf litter cover on surface runoff and soil erosion in Northern China. PLoS ONE 2014, 9, e107789. [CrossRef] [PubMed]

28. Tillman, R.W.; Scotter, D.R.; Wallis, M.G.; Clothier, B.E. Water-Repellency and Its Measurement by Using Intrinsic Sorptivity. Aust. J. Soil Res. 1989, 27, 637-644. [CrossRef]

29. Doerr, S.H.; Shakesby, R.A.; Dekker, L.W.; Ritsema, C.J. Occurrence, prediction and hydrological effects of water repellency amongst major soil and land-use types in a humid temperate climate. Eur. J. Soil Sci. 2006, 57, 741-754. [CrossRef]

30. Hallett, P.D. A brief overview of the causes, impacts and amelioration of soil water repellency-A review. Soil Water Res. 2008, 3, 521-528. [CrossRef]

31. Fodor, N.; Sándor, R.; Orfanus, T.; Lichner, L.; Rajkai, K. Evaluation method dependency of measured saturated hydraulic conductivity. Geoderma 2011, 165, 60-68. [CrossRef]

32. Jačka, L.; Pavlásek, J.; Pech, P.; Kuráž, V. Assessment of Evaluation Methods Using Infiltration Data Measured in Heterogeneous Mountain Soils. Geoderma 2016, 276, 74-83. [CrossRef]

33. Huang, J.; Hartemink, A.E. Soil and environmental issues in sandy soils. Earth Sci. Rev. 2020, 208, 103295. [CrossRef]

34. Bochníček, O.; Borsányi, P.; Čepčeková, E.; Faško, P.; Chmelík, M.; Jančovičová, L'; Kapolková, H.; Labudová, L.; Mikulová, K.; Mišaga, O.; et al. Climate atlas of Slovakia [Klimatický atlas Slovenska], 1st ed.; Slovenský hydrometeorologický ústav: Bratislava, Slovakia, 2015; p. 131.

35. International Union of Soil Sciences (IUSS) Working Group WRB. World Reference Base for Soil Resources 2014, International Soil Classification System for Naming Soils and Creating Legends for Soil Maps Update 2015; World Soil Resources Reports No. 106; International Union of Soil Sciences (IUSS): Vienna, Austria, 2015; p. 192.

36. Eijkelkamp Agrisearch Equipment. Tension Infiltrometer. User manual; Eijkelkamp Agrisearch Equipment: Giesbeek, The Netherlands, 2009.

37. Reynolds, W.D.; Elrick, D.E. Ponded Infiltration from a Single Ring: I. Analysis of Steady Flow. Soil Sci. Soc. Am. J. 1990, 54, 1233-1241. [CrossRef]

38. Eijkelkamp Agrisearch Equipment. Guelph Permeameter. Operating Instructions; Eijkelkamp Agrisearch Equipment: Giesbeek, The Netherlands, 2011.

39. Dlapa, P.; Doerr, S.H.; Lichner, L'.; Šír, M.; Tesař, M. Effect of kaolinite and Ca-montmorillonite on the alleviation of soil water repellency. Plant Soil Environ. 2004, 50, 358-363. [CrossRef]

40. Decagon Devices, Inc. Mini Disk Infiltrometer. User's Manual; Decagon Devices, Inc.: Pullman, WA, USA, 2007.

41. Dekker, L.W.; Ritsema, C.J. Fingerlike wetting patterns in two water-repellent loam soils. J. Environ. Qual. 1995, 24, 324-333. [CrossRef]

42. Hlaváčiková, H.; Novák, V.; Orfánus, T.; Danko, M.; Hlavčo, J. Hydrophysical characteristics of skeletal soils. I. Hydraulic conductivities (in Slovak). Acta Hydrol. Slovaca 2014, 15, 24-34.

43. Kirkby, M.J. Hillslope Hydrology. Landscape Systems: A series in Geomorphology; John Wiley and Sons: Hoboken, NJ, USA, 1978.

44. Zaslavsky, D.; Sinai, G. Surface hydrology: I-Explanation of phenomena. J. Hydraul. Div. 1981, 107, 1-16. [CrossRef]

45. Weyman, D.R. Throughflow on hillslopes and its relation to the stream hydrograph. Hydrol. Sci. Bull. 1970, 15, 25-33. [CrossRef]

46. Whipkey, R.Z. Subsurface stormflow from forested slopes. Bull. Int. Assoc. Sci. Hydrol. 1965, 10, 74-85. [CrossRef]

47. Zhang, Y.; Zhang, Z.; Ma, Z.; Chen, J.; Akbar, J.; Zhang, S.; Che, C.; Zhang, M.; Cerdà, A. A review of preferential water flow in soil science. Can. J. Soil Sci. 2018, 98, 604-618. [CrossRef]

48. Jačka, L.; Pavlásek, J.; Kuráž, V.; Pech, P. A comparison of three measuring methods for estimating the saturated hydraulic conductivity in the shallow subsurface layer of mountain podzols. Geoderma 2014, 219-220, 82-88. [CrossRef]

49. Li, X.; Niu, J.; Xie, B. Study on Hydrological Functions of Litter Layers in North China. PLoS ONE 2013, 8, e70328. [CrossRef] [PubMed]

50. Xiao, Q.; McPherson, E.G. Surface Water Storage Capacity of Twenty Tree Species in Davis, California. J. Environ. Qual. 2016, 45, 188-198. [CrossRef]

51. Li, Q.; Lee, Y.E.; Im, S. Characterizing the Interception Capacity of Floor Litter with Rainfall Simulation Experiments. Water 2020, 12, 3145. [CrossRef]

52. Sato, Y.; Kumagai, T.; Kume, A.; Otsuki, K.; Ogawa, S. Experimental analysis of moisture dynamics of litter layers? the effects of rainfall conditions and leaf shapes. Hydrol. Process. 2004, 18, 3007-3018. [CrossRef]

53. Zhao, L.; Hou, R.; Fang, Q. Differences in interception storage capacities of undecomposed broad-leaf and needle-leaf litter under simulated rainfall conditions. For. Ecol. Manag. 2019, 446, 135-142. [CrossRef]

54. Bulcock, H.H.; Jewitt, G. Field data collection and analysis of canopy and litter interception in commercial forest plantations in the KwaZulu-Natal Midlands, South Africa. Hydrol. Earth Syst. Sci. 2012, 16, 3717-3728. [CrossRef]

55. Buczko, U.; Bens, O.; Hüttl, R.F. Variability of soil water repellency in sandy forest soils with different stand structure under Scots pine (Pinus sylvestris) and beech (Fagus sylvatica). Geoderma 2005, 126, 317-336. [CrossRef]

56. Orfánus, T.; Dlapa, P.; Fodor, N.; Rajkai, K.; Sándor, R.; Nováková, K. How severe and subcritical water repellency determines the seasonal infiltration in natural and cultivated sandy soils. Soil Tillage Res. 2014, 135, 49-59. [CrossRef]

57. Burgeut, M.; Taguas, E.V.; Cerdà, A.; Gómez, J.A. Soil water repellency assessment in olive groves in Southern and Eastern Spain Catena 2016, 147, 187-195. [CrossRef] 
58. Gao, Y.; Liu, H.; Wu, H. Seasonal changes in soil water repellency of different land use types in Inner Mongolia grassland. Soil Till. Res. 2018, 177, 37-44. [CrossRef]

59. Hewelke, E.; Oktaba, L.; Gozdowski, D.; Kondras, M.; Olejniczak, I.; Górska, E.B. Intensity and persistence of soil water repellency in pine forest soil in a temperate continental climate under drought conditions. Water 2018, 10, 1121. [CrossRef] 